\title{
RECENT RECORDS OF BAIRD'S BEAKED WHALE IN THE JAPAN SEA
}

AUTHOR(S):

Nishimura, Saburo

CITATION:

Nishimura, Saburo. RECENT RECORDS OF BAIRD'S BEAKED WHALE IN THE JAPAN SEA. PUBLICATIONS OF THE SETO MARINE BIOLOGICAL LABORATORY 1970, 18(1): 61-68

\section{ISSUE DATE:}

1970-09-16

URL:

http://hdl.handle.net/2433/175618

RIGHT: 


\title{
RECENT RECORDS OF BAIRD'S BEAKED WHALE IN THE JAPAN SEA ${ }^{13}$
}

\author{
SABURo NISHIMURA \\ Seto Marine Biological Laboratory, Sirahama
}

With 3 Text-figures

Baird's beaked whale Berardius bairdi STEJNEger, 1883 is a ziphiid cetacean inhabiting the North Pacific waters from the Bering Sea to California in the east and to Japan in the west. In the waters adjacent to Japan, it is rather common on the Pacific side, especially around Bôsô Peninsula in central Honshu and off the Sanriku District in northeastern Honshu, and a good amount of information is available on the nature and biology of the population found there (Matsuura 1942; Omura, Fujono \& Kimura 1955; Nishiwaki 1965). On the Japan Sea side, on the contrary, the animal is seemingly rarer and there is still some taxonomic question about the identification of the specimens appearing in that sea as will be mentioned later.

The present paper is intended to introduce two records of Berardius bairdi recently made from the west coast of Honshu together with some photographic data and short notes, and to discuss the distribution and migration of this ziphiid cetacean in the Japan Sea.

Acknowledgments-The writer expresses his sincere thanks to Mr. T. Kомryama of the Kyoto Prefectural Fisheries Experimental Station and to Messrs. S. Funada and S. Hirata of the Miyazu Branch of the Fisheries Department of the Kyoto Prefectural Office for their kindness in affording him with the photographs and information on the specimen caught at Miyazu. He is also indebted to Messrs. C. Suglhara, Y. Sugryama and S. Okabe at Sakata for their generosity in offering him the photographic material and information on the specimen caught at Sakata. Dr. K.N. Nesis of the Institute of Oceanology, Academy of Sciences of the U.S.S.R., was so kind to let the writer gain access to Russian literature. Dr. T. TokiokA of the Seto Marine Biological Laboratory kindly read the manuscript. The writer's hearty thanks to all these gentlemen are due.

\section{Berardius stranded at MiyazU, Kyoto Prefecture}

On October 1, 1968, a medium-sized whale was found stranded on a shoal near Ama-no-Hashidaté in Miyazu Bay, Kyoto Prefecture in western Honshu (for the location, see Fig. 3). According to Mr. S. Funada and the staff members of the Kyoto Prefectural Fisheries Experimental Station who examined it, the animal was

1) Contributions from the Seto Marine Biological Laboratory, No. 522.

Publ. Seto Mar. Biol. Lab., XVIII (1), 61-68, 1970. (Article 6) 
a female, slightly exceeding $10 \mathrm{~m}$ in body length, slate-gray in body color and without any visible tooth on the jaws. Some photographs of this specimen were submitted to the writer for specific identification, three of which are reproduced here in Fig. 1. On examining the photographs, the writer readily recognized that the whale was Berardius bairdi. As seen clearly on these photographs, the narrow elongated snout extends forward from the well-bulged forehead, the lower jaw projects slightly beyond the tip of the upper jaw, the flippers are rather small and round at the tip, the V-shaped grooves beneath the chin, characteristic of the ziphiid whales, are well defined, and there is a conspicuous white patch beneath the throat with some additional white marks on the ventral surface between the flippers. These features are enough to identify this specimen definitely with Berardius bairdi.

Taking into account the body size, the present specimen is judged to be a sexually mature female. In this connection, it is interesting to note that the teeth are completely embedded in the gum and quite unexposed in this specimen. This is in accordance with MATSUURA's (1942) observation that the teeth at the tip of the lower jaw hardly protrude out from the gum surface in the female Berardius. In the present specimen, the forehead seemingly rises rather gently from the proximal part of the snout and consequently the transverse groove which is generally accepted to mark the transition from the snout to the forehead in adult males (PIkE 1953) is not apparent.

\section{Berardius stranded at Sakata, Yamagata Prefecture}

On October 12, 1968, another whale about $8 \mathrm{~m}$ in body length was stranded on the coast of Miyanoura, Sakata, Yamagata Prefecture in northern Honshu (for the location, see Fig. 3). Through the courtesy of Messrs. C. Sugruara and Y. Sugryama, the writer could examine some photographs of this specimen and reveal that it was Berardius bairdi. Two of the photographs are reproduced here in Fig. 2. As seen on these photographs, the animal shows every feature characteristic of Berardius: the narrow snout extends foreward from the bulged forehead, but the transition is rather gentle; the lower jaw projects beyond the tip of the upper jaw; the grooves beneath the chin are very distinct, with a white patch beneath the throat; the tail is slender and the flukes are broad, with a slight median notch on the hind margin. Although the sex was not confirmed at dissection, the features mentioned above seem to show that this individual was also a female.

\section{Previous Records of Berardius in the Japan Sea}

The Japanese name for Berardius bairdi, "tsuchi-kujira", tsuchi meaning a mallet and kujira a whale, apparently alludes to the shape of the head of the animal which must remind Japanese fishermen of an ancient mallet. Hitherto, the occurrences of 

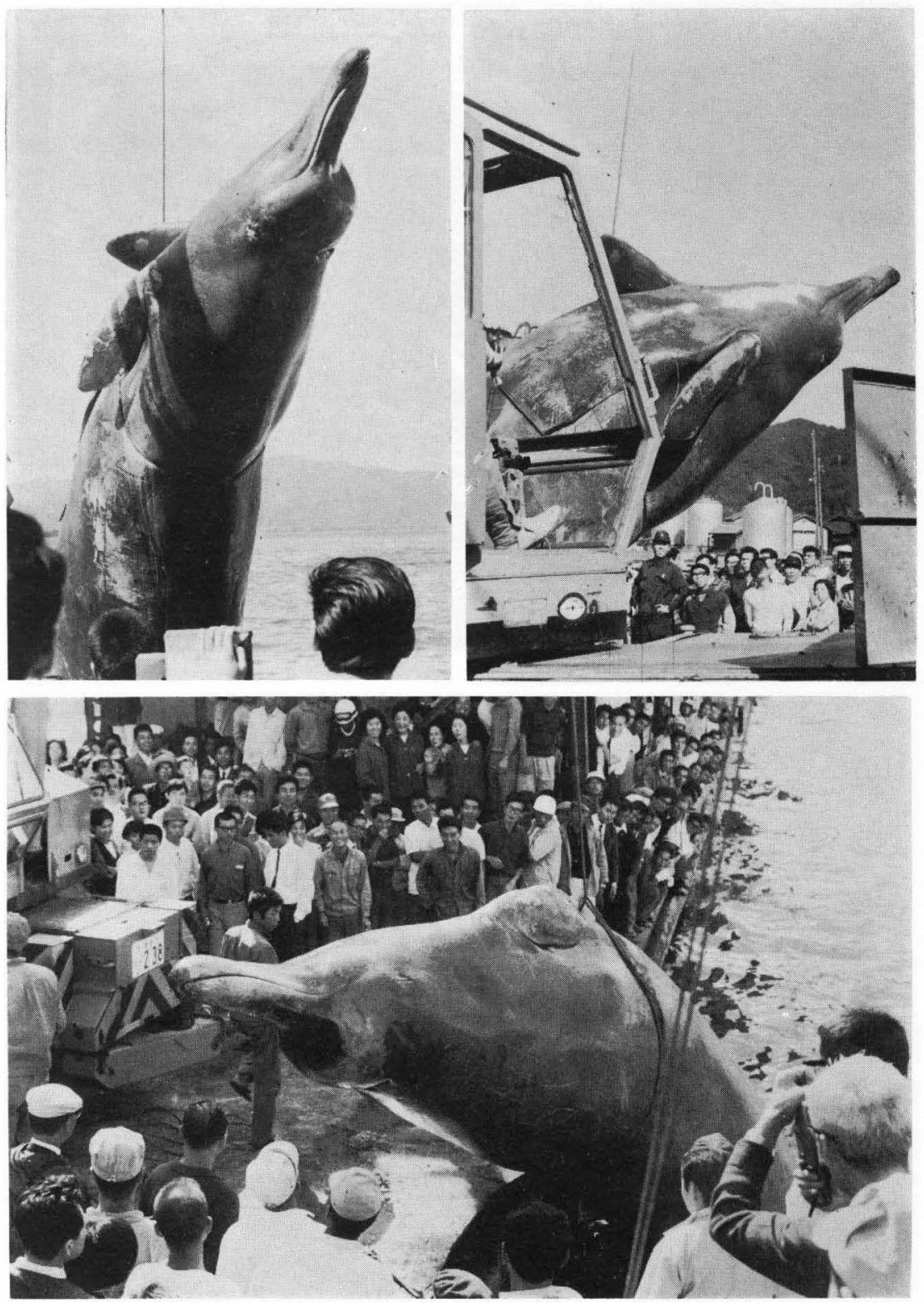

Fig. 1. Berardius bairdi stranded at Miyazu, Kyoto Prefecture, October 1, 1968. Top photographs by T. Komiyama and bottom one by S. Hirata. 

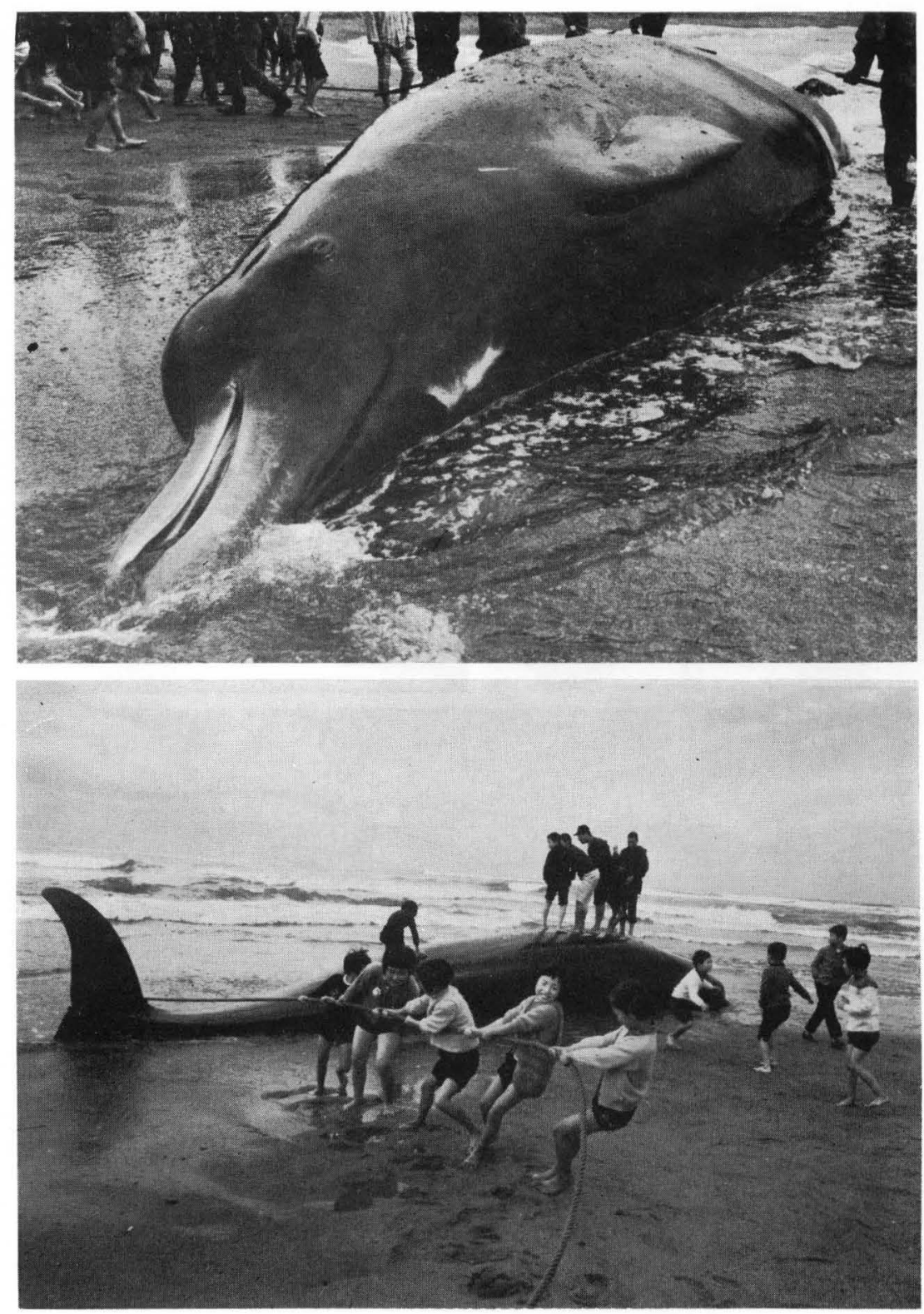

Fig. 2. Berardius bairdi stranded at Sakata, Yamagata Prefecture, October 12, 1968. Photographs by Y. SugiYama. 
the so-called "tsuchi-kujira" have not infrequently been reported from the coasts of the Japan Sea by local newspapers or publications in natural history, but most of them are much dubious about the identification. For instance, the several whales caught on the coast near Sakata, Yamagata Prefecture, from 1963 through 1966 during the season from January to April and reported all as "tsuchi-kujira" in local newspapers were really not Berardius but, judged from the photographs and accounts in the newspapers $^{2}$, some of them were supposedly Ziphius and others were Mesoplodon. All of them were 5-6 $\mathrm{m}$ long, and one of them was pregnant with a fully grown fetus $1.5 \mathrm{~m}$ long in the uterus; the latter must be a definite evidence for the fact that this individual at least can not be ascribed to Berardius.

The first record of true Baird's beaked whale from the Japan Sea was made in late April 1934 from Peter the Great Bay on the continental coast (Tomilin 1937; Zenkovich 1937); however, this was made under the name Hyperoodon ampullatus or $H$. rostratus, the names incorrectly applied to the present species at that time. It was in 1952 that this North-Pacific ziphiid was eventually identified correctly; this was made possible by the accumulated data on the related species and the detailed comparative study done by Tomilin (1952). Tomilin (op. cit.) also recorded the second occurrence of the species in the Japan Sea on a specimen observed in the area between Askold Island and Cape Gamova in Peter the Great Bay in middle April 1935. It seemed that the species was not so rare as believed up to that time. According to ZENkovich (1937), this whale was observed in the [northern] Japan Sea from early spring to late autumn, but no actual datum was presented in his description.

In 1955, Omura, Fujino \& Kimura published a magnificent paper on the biology and morphology of Berardius bairdi around Japan, in which they indicated that not a few animals of this species had been caught every year by small coastal whaling boats during the years 1948 to 1952 in certain areas of the Japan Sea such as off the west coasts of southern Hokkaido and of northern Honshu, and in Toyama Bay near Noto Peninsula (Fig. 3). The season was from June to August with a peak in July. These authors, however, did not examine those whales themselves but made identification upon the whalers' reports supplemented with the data of body length. Although they recognized that the whales caught in the afore-mentioned areas of the Japan Sea were somewhat smaller than those caught in the Pacific, they concluded "it is not probable that these whales belong to the other species of Ziphiidae (e.g. Hyperoodon), because most of them are 30 feet or over and too large to be ascribed to other species except Berardius" (Omura, Fujino \& Kimura, op. cit., p. 96). They sought the reason for the smaller size mentioned above in a possibility that only younger whales might approach the coast in these areas. Evidently, their conclusion was not completely convincing; and in fact some protestation has been made against it by a subsequent author as will be shown later.

2) The writer was granted the priviledge to examine these interesting newspapers through the courtesy of Mr. C. Sugthara, to whom his gratitude is due. 
There is also a record of the beaked whale referable to Berardius bairdi in the southern area of the Japan Sea: KamiTa (1965) refers in his book on the animals of the Oki Islands to a stranding of "tsuchi-kujira" on the coast of Tsuma, a town in the islands. According to him, the animal, stranded in late July 1964, was $11 \mathrm{~m}$ in body length and black all over. Judged by the body size, color and the season of occurrence, it seems very likely that the whale was actually Baird's beaked whale.

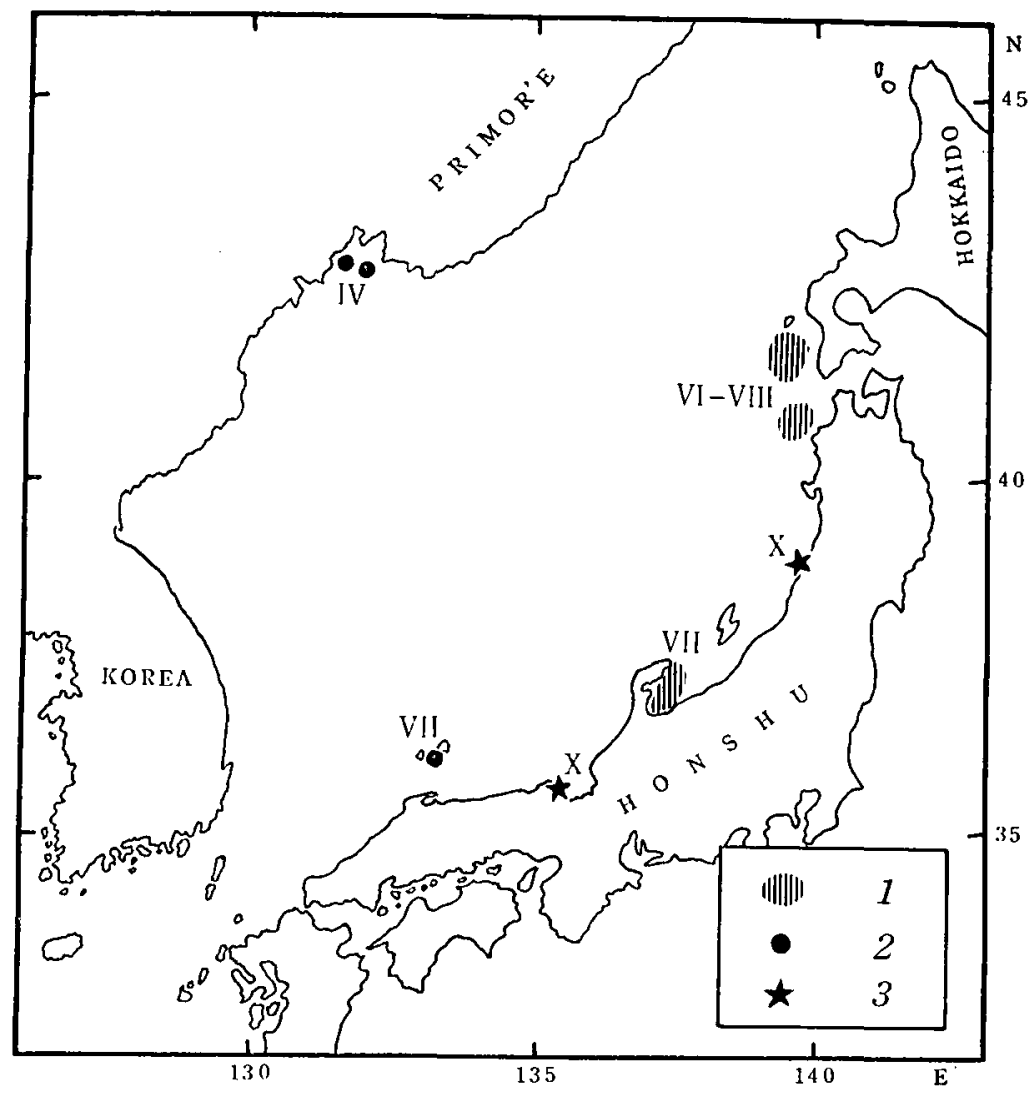

Fig. 3. Localities of Berardius bairdi in the Japan Sea.

1 - The area of occurrences reported by Omura, Fujino \& Kimura (1955); 2 Occurrences recorded by the previous authors other than OMURA, Fujino \& Kimura (op. cit.); 3-New records in the present paper. The Roman figures by respective localities indicate the months of occurrence.

Meanwhile, a question was presented by Nishiwakr (1965) on the identification of the specimens of the so-called "tsuchi-kujira" occurring in the Japan Sea. He argued that of the two populations of the "tsuchi-kujira" migrating into the Okhotsk Sea, the one found in September to October might be Berardius bairdi but the other found in April to June might really be the bottle-nosed whale Hyperoodon ampullatus (FORSTER), and that the latter population might subsequently enter the Japan Sea 
through the Sôya (La Pérouse) Straits and migrate down to the waters west of southern Hokkaido and further to Noto Peninsula (Nishiwaki, op. cit., pp. 112 and 116). His argument was based on an observation that a female of the latter population was found pregnant at the body length ca. $7.6 \mathrm{~m}$, considerably smaller than the normal body length at sexual maturity in Berardius bairdi. Nishiwakr further extended this opinion in his 1967 publication to exclude the Japan Sea from the geographic range of Berardius bairdi and to admit the area near Noto Peninsula as the unique locality in the entire North Pacific of Hyperoodon ampullatus (his Fig. 11).

At present, the writer is not in the situation to discuss about the presence or absence of Hyperoodon in the Japan Sea. However, it is now quitc undoubted that Berardius bairdi occurs in this marginal sea fairly widely off both the east and west coasts as well as in the northern and southern areas. And as seen from Fig. 3, a population of this whale seems to migrate northward in the southern half of the sea in June to August and southward along the west coast of Honshu in October. A part of this population might enter the Okhotsk Sea through the Soya Straits to be caught there in September to October (see lower lines on p. 66), but the majority might in all probability stay in the area west of southern Hokkaido or northern Honshu throughout the summer and return to the south with the beginning of the cooler season. The animals caught in the northwestern area of the Japan Sea in April may belong to another population and possibly have some connection with the population appearing in the Okhotsk Sea in April to June. Lastly, it must be noted that the migration pattern of the population in the southern half of the Japan Sea supposed above is very similar to the seasonal migration of the squid Todarodes pacificus, a very prolific warm-temperate species, in the surrounding waters of Japan (Soeda 1947; Araya et al. 1958; etc.). Similarly, the occurrence pattern of the population in the northern half of the Japan Sea may possibly coincide with the seasonal occurrence pattern of the cephalopods Gonatopsis borealis, Gonatus fabricii and Gonatus magister, the boreal or subarctic forms which are reported to constitute the staple of foods of Baird's beaked whale in the northern waters of the Far-Eastern seas and the North Pacific (Tomiln 1937, 1962).

\section{REFERENCES}

ArayA, H. et al. 1958. [Studies on "surume-ika"]. In Tsushima Danryû Kaihatsu Chôsa Hôkokusho. IV. Gyogyô Shigen Hen, i +64 pp. (In Japanese).

Kamita, T. 1965. [Animals of the Oki Islands]. Sonoyama-Shoten, Matsue, 172 pp., 4 pls. (In Japanese).

MatsuUra, Y. 1942. On the northern porpoise whale, Berardius bairdi STEjNeger in the adjacent waters of "Bôsyû". Zool. Mag., Tokyo, vol. 54, pp. 466-473. (In Japanese).

Nishiwaki, M. 1965. Whales \& Pinnipeds. Univ. Tokyo Press, Tokyo, xv +439 pp. (In Japanese).

- 1967. Distribution and migration of marine mammals in the North Pacific area. Bull. Ocean Res. Inst., Univ. Tokyo, no. 1, 55 pp., 8 pls. 
Omura, H., Fujino, K. \& Krmura, S. 1955. Beaked whale Berardius bairdi of Japan, with notes on Ziphius cavirostris. Sci. Repts. Whales Res. Inst., no. 10, pp. 89-122, 10 pls.

PIKE, G.C. 1953. Two records of Berardius bairdi from the coast of British Columbia. J. Mammal., vol. 34, pp. 98-104.

Soeda, J. 1947. Annual migration of "surume-ika" cuttlefish, Ommastrephes sloani pacificus (SteEnstruP) in the coastal waters of Japan. Hokusuishi Geppô, vol. 4, no. 4, pp. 1-24. (In Japanese).

Tomil.in, A.G. 1937. The whales of the Far East. Uchenye Zapiski Moskovsk. Gosudarstv. Univ., vyp. 13, pp. 119-167. (In Russian).

1952. [On the northern Berardius and the so-called Far-Eastern "bottle-nosed whale"]. Bjull. Moskovsk. Obshchestva Isp. Prirody, Otd. Biol., tom 57, vyp. 2, pp. 71-78. (In Russian).

1962. [The whale fauna of the seas of the U.S.S.R.] Izd. Akad. Nauk SSSR, Moscow, 212 pp., 1 pl. (In Russian).

Zenkovici, B.A. 1937. [On the migration of whales in the northern part of the Pacific Ocean]. Izv. TINRO, tom 10, pp. 3-18, 1 map. (In Russian). 